Microsystem Technologies, January 2010.

\title{
Effects of Channel Surface Finish on Blood Flow in Microfluidic Devices
}

\author{
S. Prentner ${ }^{1,4}$, D.M. Allen ${ }^{1}$, L. Larcombe ${ }^{2}$, S. Marson ${ }^{1 *}$, K. Jenkins ${ }^{3}$ and M. \\ Saumer ${ }^{4}$ \\ ${ }^{1}$ Precision Engineering Centre, Cranfield University, Bedford MK43 OAL, \\ $U K$ \\ ${ }^{2}$ School of Health, Cranfield University, Bedford MK43 OAL, UK \\ ${ }^{3}$ School of Engineering, Cranfield University, Bedford MK43, UK \\ ${ }^{4}$ Fachhochschule Kaiserslautern, 66482 Zweibrücken, Germany
}

Keywords: blood; viscosity; microchannel; roughness.

Originally presented at the DTIP 2009, Rome

\begin{abstract}
The behaviour of blood flow in relation to microchannel surface roughness has been investigated. Special attention was focused on the techniques used to fabricate the microchannels and on the apparent viscosity of the blood as it flowed through these microchannels.

For the experimental comparison of smooth and rough surface channels, each channel was designed to be $10 \mathrm{~mm}$ long and rectangular in cross-section with aspect ratios of $\geq 100: 1$ for channel heights of 50 and $100 \mu \mathrm{m}$.

Polycarbonate was used as the material for the device construction. The shims, which created the heights of the channels, were made of polyethylene terephthalate. Surface roughnesses of the channels were varied from $R_{z}$ of $60 \mathrm{~nm}$ to $1.8 \mu \mathrm{m}$.

Whole horse blood and filtered water were used as the test fluids and differential pressures ranged from 200 to 5000Pa. The defibrinated horse blood was treated further to prevent coagulation.

The results indicate that a surface roughness above an unknown value lowers the apparent viscosity of blood dramatically due to boundary effects.

Furthermore, the roughness seemed to influence both water and whole blood almost equally. A set of design rules for channel fabrication is also presented in accordance with the experiments performed.
\end{abstract}

*Corresponding author, e-mail: s.marson@ cranfield.ac.uk 


\section{INTRODUCTION}

Microfluidic devices for the manipulation of complex biological fluids are attracting considerable interest because of their potential to be applied in medical diagnostics (Tüdos et al., 2001) in the form of hand held Point of Care (POC) devices. Blood is a biological fluid of particular interest because it contains a number of different biomarkers that can provide valuable information on the health of the patients. These include for example the cardiac marker for heart diseases B-type natriuretic peptide (BNP) (Gardner et al., 2006) and the protein S100B for the early detection of stroke (Hill 2005).

Polymer microfluidic devices are suitable candidates for POC devices because they can be manufactured in high volume at an affordable cost using microreplication technologies such as hot-embossing or micro-injection moulding (Marson et al., 2007). Both these technologies require a mould (or master) being manufactured onto which the polymer is then replicated. The mould is normally fabricated out of hard metals such as steel by a variety of metal microfabrication technologies. The quality of the manufactured channels in terms of surface finish depends on the choice of the manufacturing technique and on the control of the manufacturing process.

It is well known that blood is a non-Newtonian liquid and when blood is running through tubes and vessels a cell-free layer exists near the walls (Merrill et al. 1963). The thickness of the cell-free layer increases with decreasing diameter for diameters between $50 \mu \mathrm{m}$ and $300 \mu \mathrm{m}$ (Fig. 4). It is also known from a number of previous studies, that the thickness and the viscosity of this layer with very low cell concentration is dependent on the particle size, the channel diameter and the haematocrit value (Sharan and Popel 2001).

For Newtonian liquids, Wang H. and Wang Y. (Wang and Wang 2007) reported that the higher the wall roughness the greater the velocity gradient at the channel wall. At a Reynolds number above 100 and a relative roughness (E) larger than $10 \%$, flow separation occurs and regular perturbation methods, which are typically used to predict fluid flow in a microchannel, cannot be used any more. The effect of high roughness $\left(\mathrm{R}_{\mathrm{Z}}\right)$ walls (Hodes et al., 2006) or hydrophobic surfaces (Choi et al., 2002) is better described with the Navier slip boundary model. Thus, the velocity of the bulk liquid flowing in a rough channel rises in comparison to that in a smooth channel. However, it is still unclear what influence a rough wall has on non-Newtonian liquids such as whole blood. This paper focuses on quantifying this influence in view of the choice of a suitable manufacturing process for metal micro-moulds for the manufacture of polymer microfluidic devices for blood manipulation.

\section{MATERIAL AND METHODS}

The viscosity of blood is variable and it is not possible to measure it within a channel directly. Thus, the viscosity has to be measured by calculating the 
volume flow and the differential pressure. To be able to measure these values, they must be kept constant over a certain time at a constant temperature. Therefore, in the experiments to be described, the volume flow was driven with a peristaltic pump (Minipuls3, Model M312 from Gilson Inc.), and the differential pressure was measured with pressure sensors (HCXPM005D6V, HCXM100D6V and HCX005D6V from Sensortechnics). The readout of the sensors was carried out via a LabView 8.5 program connected to an A/D converter (LabJack U3 High Voltage A/D). Using this signal the pump speed has been controlled via a closed loop-control back over the A/D converter.

The volume flow was measured by monitoring the increase in outflow blood weight (Mettler balance AT460) over a period of 10 minutes.

All experiments were performed in a temperature-controlled laboratory at $21 \pm 1^{\circ} \mathrm{C}$ and all measurements for water (used as a reference) and whole blood were repeated two or three times to check the repeatability.

Whole horse blood was obtained from TCS Biosciences Ltd. (HB035). It was delivered already defibrinated but, in addition, $6 \mathrm{~g} / \mathrm{l}$ of trisodium citrate was added to prevent its coagulation.

To magnify the effects of the inner walls on the flow, the wall surface was made as large as possible, while keeping the velocity profile along the microchannel constant. Therefore both channels (rough and smooth) have been built as rectangular conduits (Lima, 2008) with a constant width and length of $10 \mathrm{~mm}$ and with channel heights of 50 and $100 \mu \mathrm{m}$ respectively (Fig. 1). For comparison, at least two different channel heights with two different roughnesses were measured at three differential pressures (200, 300 and $400 \mathrm{~Pa}$ for the $100 \mu \mathrm{m}$ channel and $1000,3000,5000 \mathrm{~Pa}$ for the $50 \mu \mathrm{m}$ channel). The appropriate pressure range was selected to maintain comparable flow velocities for both the 50 and the $100 \mu \mathrm{m}$ channels.

For additional comparisons, a three-dimensional computational model of the device was created using commercial software (Gambit), and then FLUENT 6.3 was used to undertake the flow calculations. The model was meshed with 700,000 cells and all wall boundaries were treated as solid with a no slip condition. A velocity inflow configuration was chosen for the inlet and an outflow condition was used at the outlet.

A polycarbonate (PC) polymer sheet (Makrolon ${ }^{\circledR}$ GP clear 099) was selected for the test device. The depth of the channel was created by inserting a polyethylene terephthalate (PET) sheet $\left(\right.$ Polymex $^{\circledR}$ ) of the desired thickness between two $10 \mathrm{~mm}$ thick PC sheets and fixed in position by super glue after clamping.

The device cavities, inlets and outlets were machined on a Kern Evo Micromachining Centre.

The "rough" surface $\left(\mathrm{R}_{\mathrm{z}}=1.8 \pm 0.6 \mu \mathrm{m}\right)$ was generated by micromilling using the Kern Evo with a $1.5 \mathrm{~mm}$ endmill. The spindle speed was $10,000 \mathrm{rpm}$ and the feed rate was $750 \mathrm{~mm} / \mathrm{min}$.

The "smooth" surface was the native PC sheet (Makrolon ${ }^{\circledR}$, Bayer) as received from the supplier. The measured roughness was $R_{z}=57 \pm 2 \mathrm{~nm}$.

The total thickness of each device was measured directly by a micrometer with an accuracy of about $1 \mu \mathrm{m}$. From this measurement it was possible to calculate the actual depth of the microfluidic channels.

The roughness measurements were carried out with a Taylor Hobson Form Talysurf $120 \mathrm{~L}$ and afterwards calculated by a Scilab program. Three roughness measurements on three different regions were made on the rough 
surface and one on the smooth surface for comparison.

\section{DESIGN OF EXPERIMENTS}

The aim of the work is to measure a change of volume flow (or viscosity) by changing the inner surface roughness of the channel (Fig. 1) while keeping all the other parameters constant. The Hagen-Poiseuille equation (1) describes the change of volume flow $\left(\mathrm{I}_{\mathrm{V}}\right)$, related to the differential pressure $(\Delta \mathrm{P})$, viscosity $(\eta)$, hydraulic diameter $\left(d_{h}\right)$, cross-sectional area of channel $(A)$, and length (1) (Tipler and Mosca 2004).

$$
I_{V}=\frac{V}{t}=\frac{A \cdot d_{h}^{2} \cdot \Delta P}{32 \cdot \eta \cdot l}
$$

For a rectangular channel with the height (h) $\ll<$ width (w) of the channel and with $1 \approx \mathrm{w}$, equation 1 can be simplified to equation 2 as follows:

$$
\eta \approx \frac{h^{3}}{\mathbf{8}} \frac{\Delta P}{I_{V}} ; \text { with } \mathrm{d}_{\mathrm{h}}=2 \mathrm{~h}
$$

Equation 2 was used in this work to calculate the apparent viscosity $(\eta)$ by measuring the volume flow through the channel and the differential pressure between the inlet and the outlet at a known channel height. This experiment was repeated with two different wall roughnesses to compare the results with each other and to search for differences.

\section{RESULTS}

Figure 2 shows a $2 \mathrm{D}$ velocity slice for the $10 \times 10 \mathrm{~mm}$ microchannel. A laminar flow is clearly seen since the velocity vectors are parallel to each other with the same value of $10 \mathrm{~mm} / \mathrm{s}$ across the whole width (equal velocities at the channel exit are depicted in green in Figure 2).

The results from the ANSYS simulation show that the fluid flow conditions along the whole channel are constant; therefore the effects at the walls can be compared. Turbulences have unpredictable influences on the viscosity and therefore must be avoided. Interestingly, the predicted laminar flow characteristics have been illustrated by the presence of a separation of the flow in Figure 3 below, which traces a route across the experimental device aligned with the modelled velocity vectors. It is likely that such an unintentional feature has been caused by agglutination of blood components (cells and/or protein) at the edge of the flow inlet.

The experiments carried out on water showed that the calculated volume flow in the rough channel was significantly higher than for the smooth one. In particular, the apparent viscosity of water in the rough channels dropped to $58.1 \pm 7.8 \%$ and to $79.3 \pm 7.9 \%$ (where $100 \%$ represented the viscosity of water in the smooth channel) in the $57 \mu \mathrm{m}$ and $109 \mu \mathrm{m}$ deep channels respectively (Table 1). This suggests a decrease in the flow resistance and a decrease in the apparent viscosity that is in distinct contrast to the predictions made by previous simulations (Kulkarni, 2004). 
TABLE 1

COMPARISON OF THE APPARENT VISCOSITY OF WATER AND WHOLE HORSE BLOOD IN A ROUGH $\left(\mathrm{R}_{\mathrm{z}}=1.8 \mu \mathrm{m}\right)$ VERSUS A SMOOTH $\left(\mathrm{R}_{\mathrm{z}}=60 \mathrm{~nm}\right)$ CHANNEL (100\%). TWO DIFFERENT CHANNEL HEIGHTS AND TWO DIFFERENT BLOOD HAEMATOCRIT VALUES ARE SHOWN, $\mathrm{n}=$ NUMBER OF SAMPLES

\begin{tabular}{|c|c|c|c|}
\hline $\begin{array}{c}\text { Measured } \\
\text { channel depth } \\
(\boldsymbol{\mu m})\end{array}$ & $\begin{array}{c}\text { Apparent viscosity } \\
\text { Water }\end{array}$ & $\begin{array}{c}\text { Apparent viscosity } \\
\text { sample 1 } \\
\mathbf{( 4 4} \% \text { haematocrit })\end{array}$ & $\begin{array}{c}\text { Apparent viscosity } \\
\text { sample 2 } \\
\mathbf{( 4 2} \% \text { haematocrit })\end{array}$ \\
\hline $57 \pm 1$ & $58.1 \pm 7.8 \%$ & $66.4 \pm 2.2 \%(\mathrm{n}=9)$ & $51.6 \pm 2.7 \%(\mathrm{n}=10)$ \\
\hline $109 \pm 1$ & $79.3 \pm 7.9 \%$ & $79.7 \pm 1.9 \%(\mathrm{n}=12)$ & $77.4 \pm 3.7 \%(\mathrm{n}=2)$ \\
\hline
\end{tabular}

For horse blood with a haematocrit of $44 \%$ (sample 1) the apparent blood viscosity was reduced in the rough channels to $66.4 \pm 2.2 \%$ (where $100 \%$ is the viscosity of blood in the smooth channel) in the $57 \mu \mathrm{m}$ deep channel and to $79.7 \pm 1.9 \%$ in the device with a $109 \mu \mathrm{m}$ deep channel. The blood with haematocrit value of $42 \%$ (sample 2) showed a drop in the apparent viscosity of $51.6 \pm 2.7 \%$ in the $57 \mu \mathrm{m}$ channel and of $77.4 \pm 3.7 \%$ in the $109 \mu \mathrm{m}$ channel (Table 1).

The Reynolds numbers ( $R e)$ for the experiments mentioned above were calculated using the equation:

$$
\operatorname{Re}=\frac{d_{h} \cdot \rho \cdot v}{\eta}
$$

Where $d_{h}=2 h$ and $h$ is the channel depth, $\rho$ the density of blood $\left(1060 \mathrm{~kg} / \mathrm{m}^{3}\right)$, $v$ the velocity and $\eta$ the viscosity. The calculated Re values are reported in Table 2 together with the fluid velocity and the apparent viscosity calculated using equation 2.

It was observed that in all cases the Re for the rough channels was higher than the one for the smooth channels. This result indicates that an increase of surface roughness $\mathrm{R}_{\mathrm{z}}$ from $60 \mathrm{~nm}$ to $1.8 \mu \mathrm{m}$ lowers the apparent viscosity of the blood dramatically, probably due to the presence of boundary effects. Furthermore the roughness seems to influence both water and whole blood almost equally. 
TABLE 2

REYNOLDS NUMBER (Re), VELOCITY (v) AND VISCOSITY ( $\eta$ ) FOR WHOLE HORSE BLOOD (SAMPLE 1). THE VALUES FOR ROUGH AND SMOOTH CHANNELS ARE PROVIDED FOR TWO DIFFERENT CHANNEL DEPTHS AND THREE DIFFERENT DIFFERENTIAL PRESSURES $(\Delta \mathrm{p})$. THE ROUGH TO SMOOTH CHANNELS RATIOS ARE ALSO REPORTED FOR COMAPARISON.

\begin{tabular}{|c|c|c|c|c|c|c|c|c|}
\hline $\begin{array}{c}\text { Measured } \\
\text { channel } \\
\text { depth } \\
(\boldsymbol{\mu m})\end{array}$ & $\begin{array}{c}\Delta \mathbf{P} \\
(\mathbf{P a})\end{array}$ & $\begin{array}{c}\text { Channel } \\
\text { surface } \\
\mathbf{R}=\mathbf{r o u g h} \\
\mathbf{S}=\mathbf{s m o o t h}\end{array}$ & $\begin{array}{c}\mathbf{v} \\
(\mathbf{m m} / \mathbf{s})\end{array}$ & $\begin{array}{c}\mathbf{R} / \mathbf{S} \\
\mathbf{v} \\
\mathbf{r a t i o}\end{array}$ & $\begin{array}{c}\boldsymbol{\eta} \\
(\mathbf{m P a} * \mathbf{s})\end{array}$ & $\begin{array}{c}\mathbf{R} / \mathbf{S} \\
\mathbf{\eta} \\
\text { ratio }\end{array}$ & $\mathbf{R e}$ & $\begin{array}{c}\mathbf{R} / \mathbf{S} \\
\mathbf{R e} \\
\text { ratio }\end{array}$ \\
\hline $58 \pm 1$ & 1000 & $\mathrm{R}$ & $\begin{array}{c}6.05 \\
\pm 1.10\end{array}$ & & $\begin{array}{c}7.1 \\
\pm 1.4\end{array}$ & & $\begin{array}{c}0.11 \\
\pm 0.05\end{array}$ & \\
\hline $58 \pm 1$ & 3000 & $\mathrm{R}$ & $\begin{array}{c}19.6 \\
\pm 2.4\end{array}$ & & $\begin{array}{c}6.5 \\
\pm 1.0\end{array}$ & & $\begin{array}{c}0.38 \\
\pm 0.11\end{array}$ & \\
\hline $57 \pm 2$ & 5000 & $\mathrm{R}$ & $\begin{array}{c}31.2 \\
\pm 7.43\end{array}$ & & $\begin{array}{c}6.8 \\
\pm 2.2\end{array}$ & & $\begin{array}{c}0.62 \\
\pm 0.28\end{array}$ & \\
\hline $57 \pm 1$ & 1000 & $\mathrm{~S}$ & $\begin{array}{c}3.64 \\
\pm 0.66\end{array}$ & 1.66 & $\begin{array}{c}11.3 \\
\pm 2.1\end{array}$ & 0.6 & $\begin{array}{c}0.04 \\
\pm 0.01\end{array}$ & 2.75 \\
\hline $57 \pm 1$ & 3000 & $\mathrm{~S}$ & $\begin{array}{c}11.7 \\
\pm 2.7\end{array}$ & 1.63 & $\begin{array}{c}10.7 \\
\pm 2.5\end{array}$ & 0.6 & $\begin{array}{c}0.14 \\
\pm 0.07\end{array}$ & 2.71 \\
\hline $57 \pm 1$ & 5000 & $\mathrm{~S}$ & $\begin{array}{c}20.0 \\
\pm 4.4\end{array}$ & 1.56 & $\begin{array}{c}10.5 \\
\pm 2.6\end{array}$ & 0.6 & $\begin{array}{c}0.25 \\
\pm 0.11\end{array}$ & 2.48 \\
\hline $110 \pm 0$ & 200 & $\mathrm{R}$ & $\begin{array}{c}2.20 \\
\pm 0.09\end{array}$ & & $\begin{array}{c}13.4 \\
\pm 0.6\end{array}$ & & $\begin{array}{c}0.038 \\
\pm 0.003\end{array}$ & \\
\hline $110 \pm 0$ & 300 & $\mathrm{R}$ & $\begin{array}{c}2.87 \\
\pm 1.01\end{array}$ & & $\begin{array}{c}16.5 \\
\pm 5.8\end{array}$ & & $\begin{array}{c}0.05 \\
\pm 0.03\end{array}$ & \\
\hline $110 \pm 0$ & 400 & $\mathrm{R}$ & $\begin{array}{c}4.77 \\
\pm 0.47\end{array}$ & & $\begin{array}{c}12.5 \\
\pm 1.2\end{array}$ & & $\begin{array}{c}0.09 \\
\pm 0.02\end{array}$ & \\
\hline $108 \pm 3$ & 200 & $\mathrm{~S}$ & $\begin{array}{c}1.74 \\
\pm 0.26\end{array}$ & 1.26 & $\begin{array}{c}16.6 \\
\pm 2.0\end{array}$ & 0.8 & $\begin{array}{c}0.02 \\
\pm 0.01\end{array}$ & 1.90 \\
\hline $108 \pm 3$ & 300 & $\mathrm{~S}$ & $\begin{array}{c}2.30 \\
\pm 0.49\end{array}$ & 1.25 & $\begin{array}{c}19.3 \\
\pm 4.1\end{array}$ & 0.8 & $\begin{array}{c}0.03 \\
\pm 0.01\end{array}$ & 1.67 \\
\hline
\end{tabular}

Another experiment was carried out by changing the differential pressure in the device and calculating the corresponding blood velocity. This experiment was repeated in both rough and smooth channel devices with nominal channel depth 50 and $100 \mu \mathrm{m}$.

It was observed that an increase in the volume flow by changing the differential pressure has a small effect on the apparent viscosity of the blood (Table 2). A roughness effect can only be seen in the channels with nominal depth of $50 \mu \mathrm{m}$ (Table 2).

\section{DISCUSSION}

The results of the experiments showed a significant change of the apparent viscosity of both water and whole horse blood when comparing rough and smooth surfaces. These effects have already been observed (Hodes et al., 2006, Cohen and Feaster, 2007) but never been compared directly.

A direct comparison was carried out in this work and as a result it can be stated that water and blood flows are very similar with respect to the change in apparent viscosity within microchannels. This can be explained if we assume that the Newtonian cell-free layer which surrounds the central stream 
of the blood is the only portion of blood that is affected by the surface roughness. This assumption is supported by the observation that a decrease in haematocrit, which will increase the thickness of the cell-free layer, seems to increase the influence of the wall roughness (Table 1). Furthermore the influence of the channel roughness becomes less important with deeper channels (Table 2) (larger hydraulic diameters). It is known that in deeper

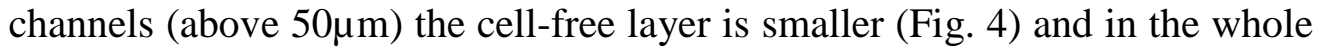
channel, the area cross-section for volume flow becomes larger (Sharan and Popel, 2001).

The reason for this effect may be a decrease in the no-slip boundary effect in smaller channels, enabling the plasma at the wall to flow with a velocity significantly higher than zero. Moreover the blood flow velocity is also dependent on the peak-to-valley roughness of the walls. For example Cohen and Feaster (Cohen and Feaster, 2007) predicted a quicker fill time of at least $25 \%$ up to more than $50 \%$ for microchannels with roughened walls compared to smooth channels. Thus there has to be a limit where the roughness will increase flow resistance and beyond which it will decrease as modeled in the simulations of Wang and Wang (Wang and Wang, 2007).

It is important to note that the plasma layer is highly dependent on the erythrocyte size which is smaller for horses $(5-6 \mu \mathrm{m})$ than for humans (8$10 \mu \mathrm{m})$ (Jain 1993). The results obtained in this work can therefore be only used to predict qualitatively the behaviour of human blood. As human erythrocytes are bigger than horse erythrocytes, it is expected that the plasma layer will be thicker (Vand, 1948, Baskurt et al. 1997). This could result in a more pronounced effect of surface roughness on human blood flow.

The results obtained are collated in Table 3 in the form of a set of design guidelines for the manufacture of blood microfluidic devices with controlled cell-free layer thickness and blood apparent viscosity.

TABLE 3

DESIGN RULES FOR VARIABLE PARAMETERS THAT INFLUENCE THE APPARENT VISCOSITY AND PLASMA LAYER OF BLOOD

\begin{tabular}{|c|c|c|c|c|c|}
\hline \multicolumn{4}{|c|}{ Variable parameters } & \multicolumn{2}{c|}{ Parameters influenced } \\
\hline Haematocrit & Roughness $\left(\mathrm{R}_{\mathrm{z}}\right)$ & Channel depth & Pressure/ velocity & Apparent viscosity & Plasma layer \\
\hline $42 \%$ & $1.8 \mu \mathrm{m}$ & $50 \mu \mathrm{m}$ & high & low & thick \\
\hline $44 \%$ & $60 \mathrm{~nm}$ & $100 \mu \mathrm{m}$ & low & high & thin \\
\hline
\end{tabular}

\section{CONCLUSIONS}

The aim of this work was to analyse the blood flow behaviour in microchannels with variations in wall surface roughness. Special attention was paid to micromilled surfaces for applications in micromoulding.

The results of the experiments showed a significant drop in the apparent viscosity in the rough-surfaced microchannel compared to the smooth one. This effect seemed to increase with a smaller channel depth and with lower erythrocyte concentration (or haematocrit value). A low haematocrit value corresponds to a thick cell-free layer (Fig. 4); therefore it is possible to state that the effect of the rough surface on the apparent viscosity increases with the cell-free layer thickness. 


\section{ACKNOWLEDGMENTS}

D.M.A. wishes to thank EPSRC for Grand Challenge grant EP/C534212/1 to research "The design and manufacture of 3D-miniaturised integrated products" (“3D-Mintegration”).

S.P. wishes to thank Kaiserslautern University of Applied Sciences for funding to carry out his research at Cranfield University.

\section{REFERENCES}

Baskurt O.K., Farley R.A. and Meiselman H.J. (1997) Erythrocyte aggregation tendency and cellular properties in horse, human and rat: a comparative study. American Journal of Physiology (Heart Circ. Physiol.), Vol. 273, Iss. 6, p. H2604-H2612

Choi H., Westin K. J. A., and Breuer K. S., (2002) To slip or not to slip - water flows in hydrophilic and hydrophobic walls. in: Proceedings of the International Mechanical Engineering Conference and Exposition, 13-16. November 2002, New Orleans, Louisiana, USA, IMECE2002-33707, pp. 1-8

Cohen D.S. and Feaster S.R. (2007) Rough channel microfluidic devices. United States Patent Application Publication No. US 2007/0140913 A1, June 212007

Gardner R.S., Chong K.S., Morton J.J. and McDonagh T.A. (2007) A change in N-terminal pro-brain natriuretic peptide is predictive of outcome in patients with advanced heart failure, Eur J Heart Fail, 9(3):266-71

Hodes M., Enright R., Eason C., Dalton T., Kolodner P., Salamon T. and Krupenkin T. (2006) Friction factors and Nusselt numbers in microchannels with superhydrophobic walls. in: Proceedings of the Fourth International Conference on Nanochannels, Microchannels and Minichannels, 19-21 June 2006, Limerick, Ireland, ICNMM2006 96134, pp. 1-11

Hill M.D. (2005) Diagnostic Biomarkers for Stroke: A Stroke Neurologist's Perspective. Clinical Chemistry 51, vol. 11, pp. 2001-2002

Kulkarni A.S. (2004) Effects of surface roughness in microchannel flows. MSc thesis, University of Florida

Lima R. (2008) In vitro blood flow in a rectangular PDMS microchannel: experimental observations using a confocal micro-PIV system. Biomed. Microdevices, vol. 10, pp. 153167

Marson S., Evans R., and Allen D.M. (2007) Replication of polymer microcomponents: the economics of hot embossing versus injection moulding, Proceedings of the $20^{\text {th }}$ International Conference on Computer-Aided Production Engineering (CAPE 2007), Glasgow, $6^{\text {th }}-8^{\text {th }}$ June 2007, Keynote paper, 2-11

Merrill E.W., Gilliland E.R., Cokelet G., Shin H., Britten A. and Wells R.E. (1963) Rheology of human blood, near and at zero flow, Effects of temperature and hematocrit level. Biophysical Journal, vol. 3. pp. 199-213

Jain N.C. (1993) Essentials of Veterinary Hematology, Chapter 2, Blackwell Publishing

Sharan M. and Popel A.S. (2001) A two-phase model for flow of blood in narrow tubes with increased effective viscosity near the wall. Biorheology vol. 38 pp. $415-428$

Tipler P.A. and Mosca G. (2004) Physik: für Wissenschaftler und Ingenieure. (Physics: for scientists and engineers) (2nd German ed.), Elsevier GmbH / Spektrum Akademischer Verlag, Heidelberg, pp. 392-417

Tüdos A.J., Besselink G.A.J. and Schasfoort R.B.M. (2001) Trends in miniaturised total analysis systems for point-of-care testing in clinical chemistry. Lab on a chip, vol. 1, 8395.

Vand V. (1948) Viscosity of solutions and suspensions II. J. Physic. and Colloid Chem. vol.52, pp. 300-314

Wang H. and Wang Y. (2007) Flow in microchannels with rough walls: flow pattern and pressure drop. J. Micromech. Microeng. vol. 17 pp. 586-596 


\section{Figures captions}

Fig. 1 Geometry of the channel within the device; $\Delta$ p: differential pressure

Fig. 2 Simulation of channel flow from top to bottom in minus y-direction showing velocity vectors and contour velocity values. Fig. 2 a) shows full section and Fig. 2 b) shows the magnified bottom right corner

Fig. 3 Blood flow through the channel of the experimental device from the flow inlet (top left) to the outlet (bottom right); the single arrow (centre) highlights the presence of a separation of the bulk flow, likely caused by blood component agglutination at the flow inlet, which is indicative of laminar flow within the channel

Fig. 4 Variation of plasma layer thickness over channel diameter and for haematocrit values $=60,45$ and 20\% (Sharan and Popel, 2001) 